\title{
TARIFFS AND TRADE IN THE COMMON MARKET*
}

\author{
Hans W. Gerhard $\dagger$
}

I

The Rome Treaty establishing the European Economic Community (E.E.C.) provides for a number of measures designed to establish an economic union between the signatory countries and make possible a more economic allocation of resources within the Community. This, in turn, would, it was hoped, increase the over-all productivity within the region comprised by the six participating countries-including certain overseas areas. The establishment of a customs union was envisaged as only one of the measures to be employed for these purposes; but, so far, ${ }^{1}$ this is the only task of "harmonization" that has reached the first stages of realization. On January I, Ig6I, tariffs on a large group of imports from member countries were reduced by a further ten per cent, after two previous reductions of the same proportion. At the same time a first step towards a common external tariff went into effect-i.e., each one of the four customs areas of the union ${ }^{1 a}$ began to apply on imports from nonmember countries a tariff which is thirty per cent closer to the common tariff provided for in the Rome Treaty.

This change in the tariff structure of the world's most intensive trading area is often regarded as an event which will have the most direct and obvious effect upon the relationship between the E.E.C. and the rest of the world. Any prediction as to the scope of this effect, however, is based largely on static models-i.e., on the analysis of cost-price-quantity relationships under extremely limiting assumptions as to market structure and income changes. Therefore, whatever tendencies or effects such models may indicate are meaningful only in the context of an extremely special case. At best, they give an indication of the direction of change to be expected from changes in tariffs; but the "tendencies" revealed by static models lack the significance of those which in reality connect different stages of economic processes over a period of time. In short, these models have only logical, rather than realtime dimensions.

Apart from the problem of prediction, one might wonder at the comparative ease with which the treaty countries have found agreement on the bulk of tariff items. If it could be argued that the establishment of the customs union was easier than the implementation of other features of economic union, one might well suggest that apparently less powerful economic obstacles were encountered in its course. Turning this argument around, this would suggest that the economic effects of

- Discussion and critique of this paper by Professors Fred Joerg, Thomas Keller, and especially Robert S. Smith, all of Duke University, are gratefully acknowledged as major aids in its preparation.

+ Dr. rer. pol. 1958, Tübingen University (Germany). Assistant Professor, Department of Economies, Duke University.

${ }^{2}$ Winter $x 960-61$.

1a Benelux (Belgium, Luxembourg, and the Netherlands) enters as one customs area. 
customs union were expected to bear relatively less on the distribution of economic gains among members than either of the other harmonization measures-i.e., common fiscal or common monetary policy. This inference seems to find some support in the general (static) theory of the economic effect of customs union.

Subject to all the limitations stemming from reliance on static models, the following conditions might be taken as a summary statement of a preliminary general theory: $:^{2}$

The over-all welfare effects of a customs union are the more likely to be beneficial:

A. The greater the gains from production expansion and trade creation; in turn, such gains are the more likely to accrue in varying proportion to-

(I) The economic importance of the area to which the tariff agreement applies. (The larger the area's share in world production, consumption, and trade, with geographic size itself an important factor in this regard, the greater will be the scope for such improvements as are generally associated with and expected from higher degrees of international specialization and reallocation of factor uses);

(2) The scope there is for "internal" economies of large scale production in such industries as may expand their production as a result of the tariff change;

(3) The difference in cost of production between the same industries in the different member countries, where they were protected by tariffs prior to the customs union arrangement;

(4) The level of the protective tariffs which are subjected either to preferential reduction or complete elimination;

(5) The competition between member countries with respect to industries enjoying high tariff protection, and the potential scope for developing complementary industries after protection is removed from the industries previously competing in the production of close substitutes; and

B. The smaller the losses from trade diversion; such losses being minimized in varying proportion to-

(x) The dependence among the member countries and their lack of dependence on the "outside" world. (If each member country is the main supplier of exports to the other member countries and is the main market

\footnotetext{
${ }^{2}$ See especially J. Viner, The Customs Union Issue 54 (1950); J. E. Meade, The Theory op Customs Union lo7 (I955); J. E. Meade, The Theory of International Economic Policy, II: Trade and Welfare (I955). For a convenient summary, see R. Sannwald \& J. Stohler, Economic Integration (1959). By introducing the concepts of "trade creation" and "trade diversion," Viner showed that the effects of customs union as an arrangement for regional free trade need not point in the same direction as the effects of universal free trade. If the customs union leads to shifts in imports from low cost nonmember countries to imports from high cost member countries, the efficiency of resource allocation will decline. To the extent that resource efficiency via product maximization enters the index of universal economic welfare the effect of trade diversion through customs union reduces rather than increases world economic welfare. For a prediction of the welfare effects of a customs union, then, it is necessary to predict the relative strengths of the forces causing trade creation and trade diversion. See Lipsey \& Lancaster, The Gerieral Theory of Second Best, 24 REv. EcoN. STud. II (1956).
} 
for exports of the other members, there is relatively little scope for damage to third countries);

(2) The insensitivity to price changes of the supply from outsiders to the member countries, and/or the insensitivity to price changes of the demand by the member countries for imports from outsiders;

(3) A low level of tariffs both of the member countries and of third countries in the lines of trade subject to the preferential tariff treatment. (In this case there has never been very much scope for distortions of the patterns of trade and production, so that the economic gains from a "correction" are correspondingly slight);

(4) The extent to which trade restrictions consist of quantitative restrictionsquotas. (Only as against either free trade or ineffective quotas can a tariff be said to have any distorting effect at all.)

\section{II}

Although only two of the model conditions just recited are directly concerned with the tariff as such, it is in each case the tariff which provides the frame of reference. Tariff rates, or rather the differences in tariff rates, serve as criteria for the grouping of countries as "members" and "third countries"-as "insiders" and "outsiders." It is as between these groupings that gains or losses are to be accounted for. Therefore, the first inquiry will be concerned with the absolute and relative level of tariffs under the provisions of the Rome Treaty.

This, of course, is not an area void of previous arrangements and still valid commitments on the part of member countries vis-à-vis the larger number of third countries. On the contrary, bilateral obligations, sometimes of long standing, and more recent commitments under the auspices of the General Agreement on Tariffs and Trade (G.A.T.T.) precondition and limit the perimeter of action. Indeed, it is still questionable whether the implementation of the Rome Treaty will be allowed to follow the presently intended design. In particular, the question of compatibility of the treaty with G.A.T.T. commitments remains under scrutiny, even if its resolution can be postponed.

While any prediction of the outcome of continued negotiation remains speculative, it is assumed that, in the absence of important shifts in power and leadership within G.A.T.T., the present attitude of general acceptance of E.E.C. by the contracting parties of G.A.T.T. will prevail long enough to allow the Common Market to consolidate on the basis of some form of preferential tariff arrangements. It is not, however, taken for granted that the final position of complete customs union envisaged by the Rome Treaty will be reached; ${ }^{3}$ instead, consolidation may be found, somewhere short of this goal.

Besides the possibility-and, indeed likelihood—of increasing pressures from third

- Complete customs union exists when internal tariffs are reduced to zero and uniform external tariffs are established for all member countries. The revenues accruing from the common external tariff are pooled. 
countries, which might stop the E.E.C. short of its goal, the case for the customs union itself must weaken during the transitional period. The additional economic gains resulting from each step of internal tariff reduction will likely decrease, whereas the losses to third countries will likely increase absolutely and/or relatively.

It is at this point that economic reasoning and wishful thinking most obviously diverge. Too much in current thought, it would seem, has come to depend upon the prediction of a mysteriously operating "internal dynamisme," sometimes more urbanely dressed in expectations of supposedly inevitable "spill-over" effects. Partly as an antidote to such exaggerated optimism, attention here is focused on the problems created-on the braking forces, rather than on the self-acceleration, of the development towards customs union. ${ }^{4}$

As far as the tariffs of the member countries on imports from each other are concerned, there is a reasonable presumption that the proposed timetable and the zero tariff target can be realized. However, even in this basically internal sphere a few snags remain-e.g., the problems of nonliberalized agricultural imports and the problem of granting largely unilateral tariff concessions of the same magnitude to the overseas territories. The timetable and the final level of the common external tariff remain much more uncertain. The recent acceleration of the first stage in aligning the outside tariffs of the four customs areas within the E.E.C. toward the common external tariff and the conditional character of the over-all reduction of this tariff by twenty per cent of its originally computed level are cases in point. These uncertainties are emphasized still more by the fact that the common external tariff has not been completed for all items traded. According to the report of the E.E.C. Commission, seventy-two items, "representing less than three per cent of the tariff lines," had not been agreed upon as of the reporting date. This report does not indicate, however, how heavily these items weigh in the total imports of the E.E.C. or in the total imports from individual nonmember countries. Without such information, the eventual over-all incidence of the common external tariff cannot be assessed. ${ }^{5}$

Apart from possible changes in policy as to time schedule and the "official" target level of the common external tariff, there remain formidable statistical problems, which make extremely hazardous any estimate of the likely effects of the common external tariff on trade with third countries. These problems result largely from the method chosen to compute the tariff. The present common external tariff is the arithmetical average of the tariffs in each of the four customs areas on January $I$, I957. This method, which gives equal weight to the tariffs in each area, has invoked much criticism. An alternative method, frequently suggested, would weight the average tariff by the relative amount of imports into the different customs areas."

\footnotetext{
"For examples of this argumentation in support of the treaty provisions, see R. SANNWatD \& J. StohIER, Economic Integration (I959). For a discussion of the "spill over effects," sec EnNst B. HaAs, The Uniting of Europe (1958).

"European Economic Community Comm'n, Third General Report on the Activities of the Community 237 (1960). The common tariff, so far, has 2,893 lines.

'Still other methods, of course, could have been employed with different weights and differing
} 
Unfortunately, no reliable method of measuring, and, a fortiori, of predicting, the effects of a tariff is available. Thus, even if it is agreed that there should be no increase, and, if possible, a reduction in the over-all incidence of the tariff, there remains some scope for differing opinions over the preferable method.

In defense of the method of computation employed, the E.E.C. Commission rejects the criticism that the common external tariff violates the G.A.T.T. rules, which, in addition to other conditions, permit customs unions only to the extent that the common tariff resulting therefrom is not, in its effect, more restrictive than were the national tariffs before the customs union was formed. The Commission. reports in fact that the level reached is ${ }^{7}$

on the whole moderate. The weighted average rate resulting from its application to alf the imports of the Community in 1958 amounts to 7.4 per cent. From this it follows that the calculation of the tariff on the arithmetical average proved more favorable to nonmember countries than the weighted average would have done; though many people favored this latter method, the resulting level would have worked out at 9.I per cent.

Statistical problems of exact measurements aside, this level would compare with an average level of 8.I per cent if the separate national tariffs, as applicable on January $r_{\text {, }}$ 1957, were computed for the same (1958) volume of imports. In this case the common tariff would, indeed, appear as "moderate" and compatible with G.A.T.T. rules. If the twenty per cent over-all reduction were actually to come into effect, the common tariff-weighted again in terms of $195^{8}$ imports-would amount to 6.I per cent. ${ }^{8}$

Not all trading partners of the E.E.C. countries find this method of comparing the average incidence of the tariff to be acceptable as a measure of changes in the tariff's economic impact. It is true that E.E.C. imports in $195^{8}$ had declined from their 1957 volume, so that the statistics on average incidence, on the whole, overstate, rather than understate, the restrictive effect of the tariff. However, even during this: year there were a number of cases-particularly cases involving nonmember countries other than the United States-where exports to E.E.C. countries increased. Since then, moreover, total imports have resumed their previous trend of substantial annual increases. The average incidence, when computed in terms of the comparatively low $195^{8}$ imports, tends in these cases to understate the change in the restrictive effect of the tariff.

A more basic criticism of the E.E.C. Commission's calculation of the external tariff's incidence originated in the West German Ministry of Economic Affairs

degrees of economic reasonableness. For instance, instead of designating the Benelux countries as onecustoms area, these countries might have gone into the average as three different areas; and since they had the lowest over-all tariff level, this would have given them relatively more weight, thus turning theaverage of the common tariff downwards. It perhaps would have been more reasonable to weight the average according to the population within each area. Using this method, the weight given the Benelux levels would have been half that given by employing the straight arithmetical method. Consequently, the: average tariff would have turned upwards.

' E.E.C. Comm'n, Third General RePort, op. cit. supra note 5, at 238 . The later publication from the statistical office of the E.E.C. quotes a weighted average rate of $7.6 \%$. E.E.C. InFormations STATISTIQUes 244 (I960).

${ }^{8}$ E.E.C. Informations Statistiques 244 ( 1960 ). 
and was adopted by the Berliner Bank A.G. and by other important business groups in Germany and outside the Community. It is argued that the Commission's calculations are distorted in their economic significance because they fail to distinguish between protective tariffs on manufactures, tariffs on agricultural products, and fiscal (revenue) tariffs. Only the first type, it is contended, can properly be considered in determining the actual restrictiveness of the tariff on imports. On this basis, a seemingly persuasive case can be made that an increase is likely in the effective incidence of the common tariff on imports from nonmember countries. For German imports, which in I959 accounted for approximately forty per cent of all E.E.C. imports from nonmember countries, it is estimated by the Ministry of Economic Affairs that, with due weight given to commodity composition, the average incidence of the tariff on imports from nonmember countries will increase by II7.4 per cent. According to this method of calculation and taking into account imports both from member and nonmember countries, the net increase in the tariff incidence on manufactured goods imported to Germany will be around twenty-six per cent.

This result depends primarily on the decision to exclude revenue and agricultural tariffs from the computation. ${ }^{\circ}$ In fact, a few more tariff items were excluded, so that approximately seventy per cent of manufactured imports actually remained under consideration. Of course, for individual tariff items the rates are sufficiently fixed and-within the limits of general uncertainties mentioned earlier in this article -predictable for each stage of the transitory period. And, for the export-import firm, while the overall tariff incidence problem cannot be said to be irrelevant, it certainly does not add anything basically different to the normal decision-making process. The economist, however, faces a problem qualitatively different when he is called upon to estimate the overall effect of tariff changes. The abstract character of the averages involved is at the core of this problem; and, in the context of the controversy mentioned here, the different possibilities for evaluating fiscal (revenue) tariffs serve to highlight this point. It is by no means clear that their exclusion from the overall estimate made by the German Ministry of Economic Affairs is more meaningful economically than their summary inclusion in the E.E.C. Commission's reports. And yet, at least in the case of Germany, one's judgment on this point is the pivotal factor. In 1958 , for instance, imports of crude petroleum brought customs revenues of DM $45^{\circ}$ million, as compared to DM $5^{\mathrm{r} 8}$ million of customs revenues from imports of manufactures. Under the common tariff, the former imports will be entirely free from duties; and so the average tariff rate as applied to all imports could go down even if substantial increases of protective tariffs on manufactured imports went into effect. ${ }^{10}$ The economic effects which really matter-the

\footnotetext{
${ }^{9}$ Commodities covered by the E.C.S.C. and by Euratom were considered as independent from the newly constituted tariff. This would seem acceptable enough if one were to take the realistic view that only such changes can be attributed to the new tariff as actually are determined by it. On the other hand, E.C.S.C. and Euratom are parts of the same general project and should, therefore, be allowed to enter into the cvaluation of the final effects of the Common Market.

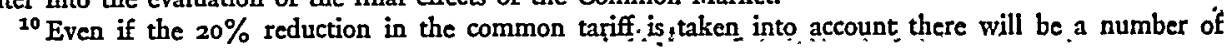


restriction of that category of imports which tends to grow most vigorously-would be covered up under the E.E.C. Commission's method of computation. ${ }^{11}$

Although the question of the proper treatment of revenue tariffs may be quite ambiguous and deceiving in the short run, there is good enough reason to include such tariffs in any long run analysis. The distinction between protective tariffs and revenue tariffs is anything but rigid; given sufficient time, a revenue tariff may well develop into a de facto protective tariff. This possibility will, of course, be modified with respect to different commodities. A given country's endowment with highly specialized production factors may well prevent a fiscal tariff from becoming, in effect, protective. In general, however, there probably would be much wider scope in E.E.C. for substitution of production factors-especially capital for laborand hence, for just such a transformation in the economic effects of a tariff. With respect to the time required for such a substitution of factors, it is significant that the length of the transitional period has been chosen specifically with a view to allowing adjustments to fairly substantial (it is hoped!) changes in the industrial structure of the member countries. If chosen adequately for this purpose, surely it will also prove adequate for such adjustments as may be necessary to exploit protective possibilities of revenue tariffs, where they are found to exist. An example would be provided by a tobacco tariff declared to be fiscal rather than protective by a country with marginal production of tobacco; this country may, in terms of pro-

fairly substantial increases in individual tariff rates, especially in the countries of the low tariff areas, Germany and Benelux. Based on Der Deutsche Gebrauchstarif 1959 and computed from a list published by Berliner Bank A.G. Mitteilungen für den Aussenhandel 12. Jg.Nr. 3, 1960, the following cases are quoted as examples. No attempt at weighting these cases for their relative importance in the total imports has been made; the importance of individual items, therefore, varies considerably.

$\begin{array}{lcc}\text { Item } & \begin{array}{c}\text { German tariff rates } \\ \text { in effect } 1959\end{array} & \begin{array}{c}\text { German tariff rates } \\ \text { in the common tariff } \\ \text { reduced by } 20 \%\end{array} \\ \begin{array}{c}\text { Automobiles } \\ \text { (passenger cars) }\end{array} & 13 \% & 23 \% \\ \begin{array}{c}\text { Radio appliances, } \\ \text { receivers, and TV }\end{array} & \mathrm{II} & 17.6 \\ \begin{array}{l}\text { Electr. household } \\ \text { appliances }\end{array} & 7 & 16 \\ \text { Machine tools } & 0-4 & 3.2-9.6 \\ \text { Textile machinery } & 0-4 & 8.8-11.4 \\ \text { Printing machinery } & 0-4 & 8.8-\mathrm{r} 2.8 \\ \text { Dairy machinery } & 4 & 8.8 \\ \text { Refrigerators } & 2-4 & 11.6 \\ \text { Leather footwear } & 8-13 & 16\end{array}$

According to Berliner Bank A.G., Mitteilungen, Nr. $9 / 10$, 1960, p. 5, the list of tariff positions increased under the common external tariff contains about 10,000 items. Most of these items refer to increases in the tariff on imports into Benclux and Germany.

${ }^{11}$ Not even the E.E.C. Statistical Office claims that no such increases in effective rates and incidence of the German tariff will result from the common tariff. In fact, it allows for an increase from $5.1 \%$ to $7.2 \%$ in the tariff incidence on German capital goods imports. This office does claim, however, that the overall effect of the common tariff as applied to German imports as a whole will be a reduction from (1957) $9.5 \%$ to $4.9 \%$ at the end of the transition period. E.E.C. InFormations StatistiQues 247 . (1960). 
ductive factor proportions available, be "unsuited" for tobacco production, if one were to take as criteria for being suited the specific factor proportions employed in the typical tobacco-growing countries. A tariff in this case might make it possible to produce tobacco in this country, since different factor proportions might then become feasible.

Even in the short run, protective and fiscal tariffs may be quite indistinguishable in their economic effects. Market responses to price changes may be induced equally well by either type of tariff and, to the extent that the rates of revenue tariffs applied to commodities are similar to those which prevail for protected commodities, the consumption contraction effect of a tariff increase and the consumption expansion effect of a tariff reduction will be similar.

In addition to the general problems of computing a common tariff and ascertaining its effects, some specific complications influence the overall level and effect of the E.E.C.'s common external tariff. For one thing, the common tariff is not computed exclusively by the averaging method. Indeed, modifications have been introduced, some of which tend to lower and some to raise, the level of the tariff. The Rome Treaty has seven lists (A-G) attached containing groups of commodities subject to special arrangements. These fall into one or the other of two categories: those where entirely new tariffs were fixed, and those where tariffs other than the ones actually in effect on January I, x957, were taken as points of reference for computing the average.

List A contains commodities for which the French tariff actually levied on January I, r957, did not correspond to the tariffs then "on the books." The tariff in these cases had been temporarily suspended or relaxed, and quantitative restrictions for the time being controlled imports of the commodities in question. List $\mathrm{A}$ represents what appears to be an economically, rather than legally, convincing solution; if the restrictive effect of the tariff provides the criterion in formulating a common external tariff, then it is quite reasonable to look for a tariff with a "restriction equivalent" to the quantitative measures being employed. However, since in no other case have attempts been made to translate quantitative restrictions into corresponding "tariff equivalents," the tariff rates fixed in list A seem rather arbitrary. ${ }^{12}$ The result is, of course, a higher level of the common tariff than would have resulted from a "legalistic" approach. With an average tariff of about twenty per cent for the seventy-three items on List A (the tariff rates ranging from six to eighty per cent),

\footnotetext{
${ }^{13}$ In general, the E.E.C. Commission has taken the view that de facto rather than de jure tariffs are to be used as bases for the averaging computation. But, in this regard, there may be some doubt as to the correct interpretation of the treaty itself. Articles 19-23-as translated into English-refer to dutics "applicable" or "applied" by the member nations. (The corresponding term in the German text is "anwendbar.") Compliance with G.A.T.T. rules could be more easily demonstrated by the E.E.C. Commission, the higher the base tariffs for the averaging could be shown to have been. Thus, the interpretation of the Treaty which is utilized may substantially affect the ease with which compliance with G.A.T.T. can be shown. Because of the divergence between de jure tariffs and actual restrictions on imports, it is not surprising that compromises such as List A were reached. Cf. Jacobi, Der kommende gemeinsame Zolltarif der EWG, 15 Aussenwirtschafr 49 (I960).
} 
the corrected increase in the common tariff has been estimated at five per cent of the tariff base, namely, the value of the imports. ${ }^{13}$

Lists $B, C$, and $D$, on the other hand, seem to indicate downward modifications of the results of simple averaging. These lists contain groups of commodities for which tariff maxima have been fixed, which in some important cases remain below the tariffs previously applied to the imports of such commodities into the individual member countries. List $\mathrm{E}$, modifying the result upwards again, contains fictitious tariff bases for chemicals to "correct" for the fact that Benelux, having no protective interest in these industries, in 1957 , levied very low import duties on imports, or none at all. Covering fifty-three items, this list is estimated to increase the common tariff by two to three per cent of the tariff base.

More important modifications of the common tariff result from special treatment of the groups of commodities in lists $F$ and $G$. Here no attempt has been made to apply simple arithmetical formulae; instead, these lists reflect negotiations and policy decisions. List $F$ contains commodities on which agreement among the member countries actually had been reached when the Rome Treaty went into effect, while list $G$ contains those items which were then still under negotiation. The former includes eighty-seven positions, with tariffs ranging from zero to eighty per cent (eighty per cent for sugar imports), and covering mostly raw materials. To the extent that previously applied tariffs are exceeded, the common tariff tends to be raised, but there are sufficiently great individual reductions to leave unchanged the general incidence on commodities in this group. There still remain seventy positions on list $G$, which represent $\mathbf{1 5 . 6}$ per cent of total E.E.C. imports from nonmember countries in 1957. Raw materials account for two-thirds of these imports, while the rest consists of foodstuffs and manufactured goods. "When these products were studied," the E.E.C. Commission reports, "it appeared that the fixing of duties gave rise to very serious difficulties because of their social and economic repercussions. In addition to these difficulties, there were the divergent interests of producer and consumer countries, which explains why some of the solutions arrived at are of a mixed type." ${ }^{14}$ Furthermore, this is not a final list, as article twenty of the E.E.C. Treaty provides for the adding of items to list $\mathrm{G}$-with a limit of two per cent of the total value of 1956 imports from third countries to the E.E.C. member which requests the addition. Additions of this type have since been requested by several member countries. ${ }^{15}$

With respect to several of the matters discussed, the situation will remain fluid, pending the outcome of negotiations scheduled for the spring of $196 \mathrm{r}$ among the contracting parties of G.A.T.T. Until then an assessment of the effect of the special treatment of commodities on the seven lists cannot be attempted. However,

${ }^{13}$ Giersch, Einige Probleme der Kleineuropäischen Zollunion, II3 ZEITSCHRIFT Für DIE GESAMTE StAatswissenchafT 602-3I (1957). Giersch also calculates that similar distortions in the common tariff, resulting from disregarding Italian tariff reductions or suspensions in force on' Jan. I, I957, have increased the tariff base $2.75 \%$.

"E.E.C. CoMm'n, Third General Report, op. cit. supra note 5, at 238.

${ }^{15}$ So-called "lists G2." 
it does seem clear that the overall level of the common external tariff of the E.E.C., as it is submitted to the G.A.T.T. parties, will be higher than an unbending application of the averaging method would have led one to expect. This is not, however, to say that the same is likely to be true for the common tariff as it will ultimately emerge from the G.A.T.T. negotiations. In fact, a proposal for a twenty per cent reduction of the common external tariff is already on the table. This proposal, made by the E.E.C. Commission in connection with the acceleration of its time schedule, remains provisional for the present, and subject to the condition of reciprocity on the part of third countries. In effect, however, it is most likely that this reduction will remain largely unilateral, since in many cases tariff agreements between at least one of the member countries and third countries exist with respect to the commodities in question. Compliance with article twenty-four, section six, of G.A.T.T. will, then, substantially mitigate any such increases as may be implied in the common external tariff. Under this provision, third countries are entitled to compensation in any such case where rates on individual tariff items are increased. Compliance with article twenty-four, section six, on the part of the E.E.C. seems beyond doubt, even if at the beginning of negotiations the Community emphasizes that it will enter such negotiations from a position of strength. ${ }^{10}$

\section{III}

The problems mentioned here should make it sufficiently clear that-quite apart from the uncertainties in the target rate and the target date of the common external tariff-the computation of average rates of incidence remains somewhat academic. This is not to say that the concept cannot be refined so as to gain real economic meaning; but that such refinement could be achieved only after considerable disaggregation of present data. To make an exact static analysis of the price-quantity effects of tariff changes and of tariff differentials, one would need a statistical device which, first, would measure both the regional (or country) and the commodity concentration of trade flows and which, secondly, would combine these measures in an index to show the degree of commodity specialization in regionally concentrated trade.

This rather formidable task of statistical analysis cannot be undertaken here, nor is it certain that at present the necessary statistical information can be obtained in suitable form. ${ }^{17}$ However, since relationships of this kind tie in directly with the general conditions determining the effects of the E.E.C. customs union on trade

${ }^{10}$ The Commission makes this sufficiently clear in its Third Report, op. cit. stipra note 5, at 385. No automatic compensation is here envisaged for each binding touched by the common tariff. "The Commission will state in respect to each binding whether it considers it subject for negotiation. In many cases, the increase of duties in certain tariffs are compensated by reductions in others; frequently this internal compensation exceeds the compensation required, and in such cases the Community must be given a credit to be set off in the negotiations on headings where the increases in duties outweigh the reductions."

${ }^{17}$ For the systematic problems involved in designing such an index of concentration, and for some empirically derived concentration coefficients, both with respect to commodity and country concentration, see Michaely, The Shares of Countries in World Trade, 42 Rev. Econ. \& Statistics 307 (I960). 
and economic welfare, it seems appropriate to point to some of the more obvious instances of trade concentration-instances that will display important features in the pattern of trade relationships between the E.E.C. and the rest of the world.

Considered together, the E.E.C. countries form the most important trading bloc of the free world. With roughly one third of the United States Gross National Product, they receive approximately twenty-two per cent of total world imports, as compared with not quite nineteen per cent for countries of the European Free Trade Association (E.F.T.A.) and approximately fifteen per cent for the United States. At the same time, the E.E.C. countries account for more than twenty-four per cent of world exports, compared with seventeen per cent for the United States and just below seventeen per cent for the E.F.T.A.18

The E.E.C. countries' importance as a world trading area increased strongly during the r950's and continues to increase at present. From I950 to I959 the value of imports into this area increased by II7 per cent, while total world imports expanded slightly more than seventy-two per cent and imports into E.F.T.A. countries sixty-nine per cent. More pronounced still was the gain in trade for E.E.C. exports, which rose by a remarkable $I 7 \mathrm{I}$ per cent, with world totals increasing just under seventy-one per cent and E.F.T.A. exports slightly more than seventy-one per cent. These figures, of course, must be modified to reflect the share of intra-E.E.C. trade.

Once the alignment to the common external tariff is under way, the "intratrade" among E.E.C. nations can no longer be regarded as "foreign" in assessing the position of the E.E.C. as a whole vis-à-vis the rest of the world. In 1959, intratrade of the E.E.C. countries accounted for about thirty-nine per cent of their total trade; this reduces and alters the trade position of the E.E.C., both in terms of absolute trade volume and in terms of shares in total world trade. In terms of actual "external" trade, the E.E.C. ranks second in exports (although the difference between the three trading areas-United States, E.E.C., and E.F.T.A.-is narrow) and third in imports behind E.F.T.A. (first) and the United States. Even then, E.E.C. imports from "outside" accounted, in 1959, for about one-sixth of the value of imports originating in the rest of the world (i.e., total world imports minus intra-E.E.C. trade). E.E.C. exports to nonmember countries accounted for more than one-fifth of world exports. The pronounced increase in the ratio of intra-E.E.C. trade to world trade provides, of course, the crucial gauge for measuring both the integrative forces of regional free trade within E.E.C. and the disruptive forces brought to bear upon the trade between E.E.C. and the rest of the world.

The E.E.C. countries have a much higher ratio of intra-trade to world trade than do the countries associated under the Stockholm Convention in the E.F.T.A. ${ }^{\mathbf{1 9}}$ This difference is fundamental since it indicates that E.E.C. is relatively less dependent than E.F.T.A. on imports from nonmembers. In light of the general

\footnotetext{
${ }^{18}$ The Soviet Area countries and Chinese Mainland are not included in "world" totals for lack of sufficiently comparable statistics.

10 1959: E.E.C. intra-trade, $39 \%$ of world exports; E.F.T.A. intra-trade, $18 \%$ for exports and $16 \%$ for imports. E.E.C. Informations Statistioues 250, 253. (1960).
} 
theory posited earlier, this justifies an optimistic view toward minimizing losses from trade diversion and damage to third countries. However, when the total external trade figures are itemized to show their regional and commodity composition, it becomes clear that there is room for severe damage in some cases. Such damage is especially likely to occur in trade between E.E.C. and E.F.T.A.

For an adequate comparison of the economic status of these two trading groups, it is not enough to compare population, geographical size, total production, consumption, and the like. In terms of such comparisons the E.F.T.A. is certainly the smaller of the two groupings; yet, in a per capita comparison, E.F.T.A. exceeds the E.E.C. in output, consumption, and foreign trade. It may well be that these latter magnitudes play a decisive part in determining the potential for further economic growth and for the expansion of trade.

The scope for damage to the trade between E.E.C. and E.F.T.A. resulting from implementation of the customs union provisions in the Rome Treaty appears considerable when present-and traditional-patterns of market interpenetration between the two areas are brought into focus. At least two countries (Germany and the Netherlands) within the E.E.C.'s "low tariff areas" have substantial export surpluses vis-à-vis E.F.T.A. countries. Moreover, in $195^{8}$, more than twenty-seven per cent of German exports, twenty-five per cent of Dutch exports, twenty-one per cent of Italian exports, and thirteen per cent of French exports went to E.F.T.A. countries. ${ }^{20}$

The importance of E.E.C. countries as markets for E.F.T.A. exports is even more pronounced. In 1959 , the ratios between exports to E.E.C. and exports to other E.F.T.A. countries were these: Austria, 49.6:10.4 (this high ratio emphasizes the political character of Austria's decision to join the E.F.T.A. and remain uncommitted as to the political implications of E.E.C.); Switzerland, 39.0:15.4; Denmark, 3r.7:40.3; Sweden, 3x.0:35.0; Norway, 27.3:37.6; Portugal (not including overseas territories) 24:17.2; the United Kingdom, I3.1:10.0.21 Changes in this pattern would seem inevitable under the provisions of both the Rome Treaty and the Stockholm Convention. Indeed, developments since 1953 indicate general shifts in trading patterns already under way. While trade among Western European countries increased on the whole by sixty-three per cent during this period, intra-E.E.C. trade rose rxo per cent, and intra-E.F.T.A. trade, thirty per cent. Significantly, although intra-E.F.T.A. trade increased at a faster rate than E.F.T.A. export trade to the E.E.C., it increased at a slower rate than E.E.C. export trade to E.F.T.A. ${ }^{22}$

While these statistics forebode losses to the participants in trade between E.E.C. and E.F.T.A., they also indicate incentives for a "bridging of the gap" between these two highly interdependent markets. Since the deficit country-or the group of Ideficit countries-typically holds the stronger bargaining position vis-à-vis a trade

$\therefore{ }^{20}$ Source: OE.E.C. Statistical BuLIETIN, Ser. I (April r959).

21 Source: OE.E.C. Statistrcar Buzletin, Ser. I (April 1959), and Berliner Bank A.G., Mittcilungen ifür den Aussenhandel No: 6/59 (1959).

${ }^{22}$ G.A.T.T., INTERAATIONAL TRADE 1959 , at.148-51 (1960). 
'partner vitally interested in preserving his export markets, the E.F.T.A., by reason of its trade position, may be in a good position to negotiate a solution of some of the problems created by the present customs union.

Two special features of the present situation make the prospects for successful bargaining appear favorable. In the first place, the present arrangement is meeting with increasing dissatisfaction in the United Kingdom. ${ }^{23}$ A review of the economic effects of imperial preferences on Commonwealth trade and a reappraisal of the question of compatibility between British membership in E.E.C. and Commonwealth ties might well alter British attitudes towards the customs union. ${ }^{24}$ In a period of vigorously expanding world trade, and even more vigorously expanding E.E.C. trade, the gains to be foregone by the United Kingdom as a result of nonparticipation in the Common Market may well appear an excessive price for the preservation of Britain's special Commonwealth position.,

Secondly, the prospect of losing important E.F.T.A. export markets has given rise to misgivings in the Federal Republic of Germany. (German opposition to the method used in calculating the common external tariff has already been mentioned.) Although Germany in terms of size and total output does not occupy the position of economic dominance within the E.E.C. that the United Kingdom holds within the E.F.T.A., it is not clear that this is the pivotal measure in assessing the weight

${ }^{23}$ The United Kingdom is singled out because of its general interest in the E.E.C. market. This is not to suggest that other E.F.T.A. countries may not have similar or stronger interests in bridging the gap. The ratios of their exports to E.E.C. countries to their exports to other E.F.T:A: countries should make this abundantly clear. If individual commodity groups of exports are considered, different industries in. the E.F.T.A. countries have, of course, much more to lose than such over-all export ratios might suggest. Sweden, in 1957 , exported $44 \%$ of its pulp and paper exports to E.E.C. countries, as compared to $35 \%$ to E.F.T.A. countries (and as compared to a reverse ratio of total exports, i.e., $31 \%: 35 \%$ ). Danish meat and egg exports figures illustrate this even more vividly.

${ }^{21} \mathrm{~A}$ change in the British attitude towards customs unions would require rather strong motives. It would mean, in the case of the United Kingdom, a reversal of firmly established conventions and principles. It should be recalled, in this connection, that Great Britain in the past has been the firmest supporter of the notion that customs unions are incompatible with the most-favored-nations principle. Cf. J. Viner, The Customs Union Issue 12 (I950). However, as Professor Viner has pointed out, there is no question that majority opinion and historical precedent favor arrangements whereby customs unions are exempted from the most-favored-nations obligations.

Actually, one might assign a less important role to the most-favored-nations principle than does Professor Viner. "The realization of a steady rate of growth, as little disturbed by cyclical fluctuations as possible, and of other important goals of economic policy, is incompatible with an unlimited application of the most-favored-nations principle." Pütz, Meistbegïnstigung, I HANDWörTERBUCH DER SozInLWISSENSCHAFTEN 288 ( 1960 ). [Writer's translation.]

With regard to Commonwealth trade and Imperial Preferences, compare The Economist INTElzigence Unit, The Commonwealth and Europe (r960). The share of Commonwealth trade on which preferential treatment makes for a substantial margin is comparatively small-approximately two-fifths of total Commonwealth exports. United Kingdom exports to Commonwealth countries, on the other hand, actually benefit more.

${ }^{25} \mathrm{~A}$ comparison of recent economic development in the United Kingdom and E.E.C. countries provides a good basis for the expectations herein expressed.

Based on figures for the first half of 1960 , British exports increased by $10 \%$ in $1959-1960$, while the index of change for E.E.C. countries was as follows: Benelux, 18\%; Germany, 21\%; France $34 \%$; Italy, $4 \mathrm{r} \%$.

British industrial production rose by 10\%; Benelux, 12\%; Germany, 15\%; Italy, $18 \%$.

1 The United. Kingdom during the fear September 1959 to September 1960 , lost $5 \%$ of her gold and foreign exchange reserves, while the E.E.C. countries together, increased such reserves by $24 \%:$ : 
of German influence. ${ }^{26}$ Rather the measure may depend on the share in trade of the area as a whole. In this latter respect, Germany's position in the E.E.C. is similar to the position held by the United Kingdom in the E.F.T.A. Moreover, Germany's export surpluses with the smaller E.F.T.A. countries account almost exclusively for the E.E.C.'s net creditor position vis-à-vis the E.F.T.A.

In light of the German and British trading interests at stake, these factors may create a bargaining atmosphere more conducive to compromise than could be expected with a more symmetric pattern of intra-European trade. So far, it has been the policy of the E.E.C. Commission to offer "negotiations" with the United Kingdom on the condition that the provisions of the Rome Treaty are to be fully accepted by any country joining the union. This position is likely to prove untenable; after all, each of the treaty provisions is the result of lengthy negotiations between the signatory countries. It would seem quite unreasonable to expect the United Kingdom to join-if she so desired-without substantial bargaining and renegotiating of at least parts of the treaty.

In trade with third countries-i.e., with countries which are neither E.E.C. nor E.F.T.A. members-similar concentration patterns are evident. Although a further breakdown according to the regional concentration of E.E.C. trade or the shares therein of individual third countries cannot be attempted here, at least a general indication of the commodity composition of such trade may be given. ${ }^{27}$ The special features of E.E.C. trade emerge best from a comparison with E.F.T.A. countries' trade with third countries.

E.E.C. imports from third countries in 1959 exceeded corresponding E.F.T.A. imports by slightly more than one billion dollars. Foodstuffs and manufactures, however, weighed more heavily in E.F.T.A. imports and actually exceeded E.E.C. imports in value. The larger E.E.C. total, then, is wholly accounted for by the larger pro-

${ }^{26}$ At least one opinion should be quoted as not in concurrence with this quantitatively conceived statement. E. Strauss, Common Sense About the Common Market (I958), sees "the truc motive forces behind the Rome treaty, in German interests. The unmistakable power centre of the new block is the German Federal Republic directed by the rulers of German industry, which has successfully harnessed the urges and aspirations of the dominant social forces and the hopes and fears of many people in Western Europe to the service of a combination promising to be of great benefit to Western Germany in general and to its business interests in particular." Id. at 7. After an excursion into the history of the common market idea in German thought, the author concludes: "By committing the future of European economic integration to the care of Western Germany, the signatories of the treaty ... have embarked on an unjustifiable gamble." Id. at I27.

For a more structured view of German industrial interests in the "integration," compare ERNST B. HAAs, The Untring of EURope I62-76 (1958).

Also, the more recent opposition of infuential industrial groups in Germany against some of the implications of E.E.C. tariff policy indicates a much looser connection between German interests and E.E.C. than the political history of the treaty negotiations might suggest.

${ }^{27}$ For a detailed analysis of trade between E.E.C. and a number of individual third countries, sce P. Erdmann \& P. Rogge, Die Europäische Wirtschaftsgemeinschaft und die Drattiñnder (1960).

For E.E.C. trade with the United States, see Kreinin, European Integration and American Trade, 49 AM. Econ. Rev. 6I5 (1959). See also Comm. on Foreign Affairs, Report of the Special Study Mission to Europe, H.R. REP. No. 1226, 86th Cong., 2d Sess. (1960), and Hearings Before the loint Economic Committee on Employment, Growth, and Price Levels pt. 5, International Influences on the American Economy, 86th Cong., Ist Sess. (1959). 
portion of crude materials imports. ${ }^{28}$ With the exception of manufactures, imports from third countries accounted for more than half of all commodity imports into both the E.E.C. and the E.F.T.A. In short, only in manufactured goods is trade between the E.E.C. and E.F.T.A. the predominant element, while for imports of foodstuffs and crude materials both areas depend heavily on third countries. This dependence is more pronounced in the case of the E.F.T.A. than of the E.E.C. However, with respect to imports from the United States, the E.E.C. accounts for a larger absolute value and a larger share. This is partly explained by the predominance of crude materials imports among total E.E.C. imports, and also by the much larger E.E.C. imports of American manufactures. ${ }^{29}$

These figures must, of course, be seen against the background of changing trade relations between western Europe as a whole and the United States. What otherwise might appear as trade diversion resulting from E.E.C. tariff policy may, after all, represent nothing but a continuation of trends well under way before the Common Market and for quite different reasons. With as much as forty per cent of total American exports going to western Europe in 1928 and as little as seventeen per cent in 1953 , there is, indeed, a strong case for holding the latter view. Obviously, with the disruption of trade in the world depression and during World War II, there is little hope of uncovering the purely commercial "causes" underlying such changes. At any rate, in 1959, western Europe (the Organization of European Economic Cooperation (O.E.E.C.) countries) received just under twentyfive per cent of exports from the United States.

Only a breakdown of commodity composition will lead to some insight into the prospective effects of the Common Market on trade with the United States. The most important commodity group comprises foodstuffs, of which the O.E.E.C. countries received forty-one per cent of the United States exports. In so far as American exports of crude materials and manufactures were concerned, the O.E.E.C. countries accounted for thirty-five and fifteen per cent respectively. Since agricultural production in Common Market countries is expected to grow at approximately four times the rate of population growth, a declining E.E.C. share in total American agricultural exports is easily foreseen. Even if the outcome of agricultural integration in the E.E.C. remains uncertain and even if the development of Common Market policies towards the overseas territories is regarded with some scepticism, overproduction in grain seems most likely. Moreover, self-sufficiency in most other

${ }^{28}$ Imports from third countries (in billions of dollars and percentage of total imports):

E.E.C.

E.F.T.A.

Foodstuffs

Crude Materials

Manufactures

Source: O.E.E.C. Foreign Trade Bulletin Ser. B and C (I960).

${ }^{20}$ E.E.C. countries in 1959 imported more than twice the value of E.F.T.A. imports from the United States in this category. In all three categories together, E.E.C. imports from the United States account for $22 \%$ of the total commodity imports as compared to $17 \%$ in the case of E.F.T.A. In manufactures, E.E.C. imports $14 \%$ more from the United States than E.F.T.A. O.E.E.C. ForeigN Trade BulletiN Ser. $B$ and $C(1960)$. 
agricultural products of the temperate zones (other than raw materials) seems well within the realm of possibility. ${ }^{30}$

Quantitatively more important to the United States are the prospects for exports of crude materials to the E.E.C. In 1959, the E.E.C. accounted for twenty-five per cent of American exports in this category, as compared to twenty per cent of foodstuffs exports. ${ }^{31}$ In this commodity group, there seems to be relatively little room for tariff discrimination, since the major portion will enter the Common Market duty free. However, in some cases, such as coal and crude petroleum, special regulation by the High Authority of the European Coal and Steel Community may effectively limit the quantities allowed to enter the Common Market area. There is also a tariff, ranging from two to five per cent, on vegetable oils and fats, products for which the E.E.C. provides the largest United States export market, but the restrictive effect is likely to remain negligible. ${ }^{32}$ The only severe case of discrimination is aluminum, with a tariff rate of ten per cent. ${ }^{33}$

Decisively bleaker is the outlook for American exports of manufactured goods, which by far provided the strongest tie in United States-E.E.C. trade as of 1959. However, the E.E.C. market accounts for only about ten per cent of total United States exports in this category.

Were it not for the fact that American foreign economic policy remains committed to a program involving heavy unilateral spending abroad; one could certainly conclude that "the impact of European integration on aggregate American production is not likely to be significant; because foreign trade plays a relatively unimportant role in the American economy."34 As it is, discrimination in manufac-

- ${ }^{30}$ Cf. Frutz BaAde, Die deütsche Landwirtschaftschaft im Gesceinsamen Markt (1958). For production possibilities and market conditions of grains, especially with regard to France and Tunisia, and for a survey of EE.C. grain policy proposals, see F. C. FABRE, LA politique cérétalière en Europe AU SEUIL dE L'UNIFICATION (Aspects EURoptens No. 3) (I96o).

" ${ }^{31}$ In 1928, this category accounted for $40 \%$ of United States exports as against $20 \%$ in 1959 . From 1957 to 1959, United States exports of crude materials decreased by $44 \%$. Not all of this decrease can be explained by a change in the relative availability of the products in this category. Part of the explanation must be seen in the fluctuation of economic activity in Europe. It is in this respect that the much cited dependence of Europe on cyclical fluctuations in the United States might well be reversed in the future, if, indeed, such reversals might not already be observable. In 1958-59, the decline of crude material exports from the United States coincided with a $6 \%$ increase in imports. The outstanding feature in that period was, of course, the decline of $64 \%$ in iron and steel exports in consequence of the steel strike. The relatively mild increase in iron and steel imports $(20 \%)$ points to structural rather than cyclical factors ("excess-capacity").

. 32 The rates of 2 to $5 \%$ apply to inedible fats and oils, which are practically all the United States exports to E.E.C., in this category, Higher rates apply to edible fats.

${ }^{83}$ The value, of aluminum exports in 1959 was approximately $\$ 20,000,000$.

${ }^{84}$ Kreinin, supra note 27 , at 626 . The estimates offered by this author place the share of total United States exports likely to be injured by the E.E.C. at $5 \%$. Mr. S. Stewart, of the British Board of 'Trade, in an unpubliskied' paper, estimates that 20 to $30 \%$ of total United States exports are likely to be, affected. This drastically different estimate occurs because this author gives more weight to the fact that, in 1959, of total imports of engineering products into the O.E.E.C. countries from third countrics, $73 \%$ originated in the United States. Furthermore, since the low tariff areas of the E.E.C. accounted for more than half of these imports, the tariff increases must be expected : to have especially stronts impact. As Germany accounts for as much engineering production as the rest of the E.E.C. countries together, the internal tariff elimination will also be more likely to have stronger effects upon trade in: this commodity group with the United States. 
tures-the very category of exports in which the United States has shown the most promise for production and trade expansion ${ }^{35}$-may come to bear more heavily on the American economy than would be suggested by the relatively small role exports play in creating United States national income. The result will depend largely upon the possibility of expanding American exports to other countries, as the United States has already done with some of its manufactured goods. On the whole, a comparison of American export performance with that of Western Europe tends to be prejudiced by the large share of western European exports accounted for by Germany. The special factors underlying West German economic growth, and particularly the special stimuli provided for German exports by an export-conscious governmental policy, do not justify any prima facie conclusions concerning the commercial competitiveness of United States exports.

Any attempt at forecasting the long-run effects of -E.E.C. integration must place the present pattern and any short-run changes in trade relationships between E.E.C. and the rest of the world into the context of past developments and the potential for economic growth. Such a task is formidable, because potential growth in E.E.C. economies may depend markedly on the effects of integration itself; indeed, the rationale of the whole venture is to achieve such integration effects. At best, from the forecaster's point of view, hitherto observable trends will continue along established paths, and the "integration effect" will come into play only with the "official" beginning of the step-by-step integration schedule. At worst, the E.E.C. provides an altogether unique case, with patterns of development determined by the special features of the participating countries and with the "integration effect" largely preempted by anticipatory adjustments of economic activity within the Community and in third countries.

Many factors point to the latter possibility-the rather unique structure of E.E.C. trade and the strong influx of foreign capital into the Common Market providing the more obvious illustrations. Accordingly, the various forecasts on rates of economic growth within the E.E.C. differ widely: most estimates concur, however, in placing the minimum average annual growth rate at 3.1 per cent. ${ }^{36}$ If due consideration is

\footnotetext{
${ }^{35}$ Exports in metal manufactures and railway vehicles to markets other than Western Europe or Canada increased between' 1953 and 1958. Exports of chemicals, aireraft, and paper increased even in western European markets. See U.N. ECONOMIC COMM'N fOR EuRope, Economic SURVEY of EuRope iN 1959, I3-15 (E/ECE/383) (U.N. Pub. Sales No.: 6o.II.E.I). U.S. Dep't of Commerce, Survez of Current Business iI (Dec. I960), reports a steep increase in the over-all merchandise trade surplus during the third quarter of 1960. Steel, cotton, and aircraft exports accounted for almost two-fifths of the expansion in exports. Passenger cars, copper, and aluminum contributed an additional one-fourth of the total improvement in the United States balance of merchandise trade.

${ }^{80}$ The G.A.T.T. Secretariat forecasts an increase in GNP by $90 \%$ over the period 1953-55-1973-75 for the E.E.C.; see The Possible Impact of the European Economic Community, Trade INTELIIGENCE PAPER No. 6 (-1957). The average annual growth rate; in this case, would-be $3.3 \%$. This estimate was amended to take into account a special integration effect on growth. The total GNP increase over-the same period was placed at a minimum of $120 \%$ and a maximum of $150 \%$, with average annual rates of $4.0 \%$ and $4.7 \%$.

The List Gesellschaft, Research Department (Basle), in a more recent estimate, gives a figure of $113 \%$ for the total increase in GNP from 1955 to 1975 , and an average aninual rate of $3.8 \%$. This forecast places the prospective annual rate for the period $1955-65$ at $4.3 \%$, and for the period $1965-75$ at $3.4 \%$.
} 
given to the special fáctors determining the growth leaders of recent years and to the fact that growth leadership shifts from country to country, ${ }^{37}$ this conservative estimate appears quite acceptable.

When even the minimum projected E.E.C. growth rate is compared with such rates in nonmember countries, substantial differentials are likely to appear ${ }^{38}$ which, however, need not adversely affect trade. Rising national incomes and reversals in the terms of trade may well result in nonmember countries receiving a bigger share of trade gains. However, such optimistic results will come about only under special conditions in the world trade structure, which recent developments in international trade indicate: do not exist. In the first place, the unusually high rate of annual increases in the volume of world trade (six to eight per cent over the I948-I958 period) cannot be expected to continue very long. Secondly, the danger of trade diversion damage is aggravated by the long-run tendency for trade between industrial countries and nonindustrial countries to decline relative to total world trade..$^{39}$ Thirdly, the long-run tendency towards regionalization may well continue to prevent an optimal pattern of trade between the E.E.C. and other industrialized countries, including the United States. ${ }^{40}$

P. ERDMaNn \& P. Rogge, Die EuRopäische Wirtschaftsgemeinschaft und die Drutthänden I33 (Ig60). (These authors also list and analyze forecasts given by other official and private institutions.) As to the more immediate prospects, Mr. Robert Marjolin, Vice President of the European Economic Community, in a speech on Jan. I9, 196I, predicted a rate of 4 to $5 \%$ in real GNP for 1961 , which compares to a rate of almost $7 \%$ realized in rg6o. European Community, Information Scrvice, Washington, D.C., Jan. 23, 196r.

${ }^{37}$ At present, the shift appears to be from Germany to Italy and France. See note 25 stupra. For the problems encountered in analyzing the factors determining economic growth in Germany, see Sohmen, Competition and Growth: The Lesson of West Germany, 49 AM. Econ. Rev. 986 (1959), and the comments on this article, especially by Roskamp, $50 \mathrm{id}$. at 1015 (1960).

${ }^{88}$ G.A.T.T. estimates an average annual growth rate of $2.6 \%$ for the European countries outside E.E.C. See The Possible Impact of the European Economic Community, supra note 36.

${ }^{30}$ Cf. P.l. Yates, Forty Years of Foreign Trade 56 (1959).

${ }^{40}$ Erik Thorbecke, The Tendency Towards Regionalization in International Trade, 1928-1956 (I960) argues that monetary and political forces, rather than tariff barriers, have brought about an increasing degree of regionalization in international trade. Three regions examined by Thorbecke are the O.EE.C., the Sterling Area, and the Dollar bloc. Intra-regional trade as a ratio of total trade of these areas is found to have increased from $48.8 \%$ in 1928 to $57.8 \%$ in 1956 for exports, and from $41.6 \%$ to $5 \mathrm{I.4} \%$ for imports. As a ratio of total world trade, intra-regional trade increased from $15.6 \%$ to $18.8 \%$ for exports, and from $15.0 \%$ to $19.0 \%$ for imports. The author concludes "that the rise in intraregional trade which took place between 1938 and 1956 within the smaller European countries reflects to a large extent a more efficient use of the existing natural complementarity, which was made possible by significant changes in the over-all state of technology." Id. at 126. It is largely on the basis of technological considerations that Thorbecke gives a rather optimistic outlook on the effects of the E.E.C. He assumes a rather substantial scope for economies of scale and the concomitant improvements in resource productivity. . Other authors are much more skeptical with respect to foreseeable economies of scale. Cf. Johnson, The Economic Gains from Freer Trade with Europe, The Tree Banks Review, Sept. 1958, p. 9, and P. Erdmann \& P. Rogge, Die Europärsche Wirtschaftsgemeinschaft und die DRITTLÄNDER 35 (I960).

This asymmetrical pattern of world trade expansion was repeated in European trade; and with the resumption in 1959 of a high rate of economic growth, western European trade continued to expand vigorously. While intra-European trade accounted, on the whole, for the biggest share, the less industrialized western European countries were "hardly touched" by this trade expanision. "Increase countries," on the other hand, accounted for $73 \%$ of the intra-European imports, and for nearly $80 \%$ of the increase in such exports. U.N. ECONOMIC COMM'N FOR EUROPE, ECONOMIC SURVEY of EUROPB IN I959, at 7 (E/ECE/383) (U.N. Pub. Sales No.: 6o.II.E.x). 
Here again, the impact of the E.E.C. upon trade with nonmember countries cannot be judged by aggregate statistics, for the effects on the group of nonindustrialized or less industrialized countries as a whole do not determine the results for individual countries in the group. Growth rate differentials within the group may worsen the trade position of individual countries. As to the commodity compositions of these countries' trade, there exist, of course, as many terms of trade as there are pairs of commodities traded. ${ }^{41}$

Even if sufficiently specific information can be obtained about the effective rates under the E.E.C. common external tariff, and if the structure of trade between the Common Market countries and outsiders is sufficiently analyzed, the likely effects of the E.E.C. tariff remain uncertain. Price effects are directly proportional to tariff changes only in the case of perfectly competitive markets in trade participating countries. If imperfections exist, tariff changes are much less likely to be transmitted to prices. Both lack of sensitivity to price changes on the side of demand and the ability to engage in some measure of "price policy" on the side of supply would account for such possibilities. In either case the theoretically possible price effects would be of different magnitudes for changes within different price ranges. On the other hand, tariff changes are likely to have stronger price effects than the general theory would suggest, since customs evaluation practices, as a rule, are such as to reinforce the price effects of tariff changes. ${ }^{42}$

With respect to the "welfare effects" resulting from a comparison of "tradecreating" and "trade-diverting" effects of the E.E.C. customs union, there is some room for doubt whether the preferential tariff arrangement of this customs union will disturb the optimal economic pattern of world trade. Particularly with respect to the postwar period and in light of some fairly obvious disparities in foreign exchange rates, there is little to suggest that trade flows actually correspond to any such optimal pattern, either in the direction or in the commodity composition of trade. Of course, as was shown above, this statement does not mean that serious

11 The "terms of trade" concept, as usually employed in analyses of changes in a country's trade position, is a highly aggregative statistical device involving index numbers. It does not directly measure gains or losses from trade. These are measured only by changes in net income. Cf. Flexner, An Analysis of the Nature of Aggregates at Constant Prices, $4 \mathrm{I}$ REV. Econ. AND STATISTICs 400 (I959).

Terms of trade have been found to favor developed countries as against underdeveloped countries in the long run. The empirical record does not, however, show that terms of trade moved at the same time in favor of manufactures and against primary products, as might have been expected. Cf. C. P. KINDLEberger, The Terms of Trade: A European Case Study 253 (1956). This, too, would suggest extreme caution with respect to generalizations on the basis of aggregative terms of trade concepts.

See also G.A.T.T., InternationaI Trade 1959, at 36 ( 1960 ): "Changes in terms of trade gave North America and Western Europe an increase in real national income which can (for the period 1953-58) be roughly estimated at about $\$ 2,800$ million at 1953 prices. At the same time, however, the changes in terms of trade decreased the import capacity, and probably also the imports, of the nonindustrial areas by about $\$ 1,700$ million, resulting in a net gain from improved terms of trade for the industrial areas of about $\$ I, 000$ million."

${ }^{2}$ This is especially true for the treatment of discount, rebate, and certain tax compensations upon crossing a customs barrier. The customs duty is in such cases usually added to the "custom value" on the basis of which it has been computed. The compensation is then charged as against this higher "base value," and has, therefore, a cumulative effect on price. Cf. Jürgensen, Die Wirtschaftsgemeinschaft im Freihandelstaum, I JaHrbUCH Für SOZIALWISSENSCHAFT 53 (I959). 
damage is unlikely to occur in individual (industry or country) cases. It is suggested, however, that such damage often occurs only because industries or countries have adapted themselves to patterns of trade which are far from optimal and, therefore, basically unstable.

Also, it must not be assumed that tariffs always have been the major factors in distorting international trade. Indeed, quantitative restrictions and exchange controls during the post-depression period may well have been the more important instruments in restricting and rechanneling international trade. ${ }^{43}$ In this connection it is significant that the E.E.C. treaty does not contain any direct provisions for the removal of quota restrictions on trade with nonmember countries. Although the treaty provides for lifting quotas in intra-E.E.C. trade along with the step-by-step elimination of tariffs, nonmember countries must rely for relief on the general commitment of the E.E.C. Commission to the principles of a "liberal" commercial policy. ${ }^{44}$

There remains, then, an important reservation: whatever the structure of trade between E.E.C. and nonmember countries, and whatever the final rates of the E.E.C. external tariff, the establishment of a customs union among the six countries of the European Economic Community is no substitute for other tasks of common economic policy.

48 The assumption that the effective rates of tariffs just "fit" the relative cost situation of trade competing industries, and therefore give a correct measure of protection and trade restriction, would imply a presumed economic rationality in the use of the tariff, and in the fixing of its rates, which neither the normal administrative procedures nor the actions of interest groups promoting a tariff seems to warrant.

"Certain quota concessions were made by the E.E.C. to G.A.T.T.-member countries in 1959. At present, a complaint by Australia against the agricultural quota set by the Federal Republic of Germany is pending under G.A.T.T. procedure. See Die Welt, Feb. 25, 196r, p. 7. 